out i 80 pieces, and there were still left numerous small particles which could be felt but not separated from the water.

I have been induced to bring this case into notice, as quite recently I observed one of a similar nature reported at a meeting of one of the Veterinary Associations. In the latter instance the bone was broken (if I remember aright) into fifty pieces. At the time I read the report I considered the case a very extraordinary one, and probably unprecedented, but judge of my surprise when in about a week afterwards the case which I have just described took place in my own experience.

One would be inclined to imagine it quite outside the bounds of possibility that a short, strong bone like the os suffraginis should be so utterly destroyed by any force that could be produced by a simple fall.

\title{
EQUINE TUBERCULOSIS.
}

By BenJamin FreER, M.R.C.V.S., Uppingham.

EARLY in September I886 I was requested to look at a well-bred yearling colt which I had castrated in the previous June, and which, the owner said, had not done well since. I saw him the following day, and careful examination showed nothing resulting from the operation. The colt looked starved, and had lost his muscle, in fact, had evidently been doing badly for some time. I attributed this partly to the poverty of the land, and partly to the fact that for some time we had been having very inclement weather. I ordered him into a roomy and comfortable box, recommended a diet of bran, oats, good hay, plentiful supply of rock salt, and good water, and sent him a dozen powders containing ferri sulph., gentian, etc., fully expecting to find an improvement the next time I called. I was not disappointed, and for some time the improvement continued, but, passing one day, I was asked to call as the colt was in pain. I found him rolling about, sweating profusely, and tympanitic. Having nothing better with me, I gave him an 8-oz. bottle of wound liniment-ol. tereb. and ol. olivæ, and this gave almost instant relief. However, he now had occasional attacks of this sort, which soon became more frequent, although they were invariably relieved by a draught containing ather sulph. and tinct. opii. Every time I saw him it became more and more apparent that he was doomed. I gave him sodæ hyposulph. and nux vomica, potas. chlor,, cinchona, liq. arsenicalis, ol. morrhux, etc., but nothing seemed to do him any permanent good. As I had sometime previously given it as my opinion that it was a case of consumption of the bowels, the owner at last determined to destroy him, but was saved the trouble as the animal went off suddenly during one of his periodic attacks.

I made a post-mortem examination the same day, and found the mesentery studded with apparently tuberculous deposits. One mass in the lumbar region, consisting of a number of tumours of various sizes, was undergoing the softening process. The bowels were very pale and full of wind. Kidneys and liver pale, the latter having several small deposits in its substance. 
On inquiring as to the health of the dam, I was told that from a foal she had always been remarkably healthy, had been an extraordinary good hunter, and a winner of steeplechases. She had had two foals previously, of which more anon. Private inquiries as to other foals by the same sire gave me no clue, and probably the case would have been forgotten; but in the following March 1887 I was asked to see a fouryear-old colt out of the same mare, and belonging to the same owner. He had been pricked by the blacksmith whilst in training for a race, and as considerable suppuration, and consequent removal of sole, had taken place, he was turned out of training. After attending him about a week, I lost sight of him until the following July, when I remarked his lusty appearance. Early in August he was reported to be losing flesh, and I was requested to see him. I found that he was apparently suffering from indigestion, sent some balls for him containing aloes barb., sodæ bicarb., and nux vomica. Two or three days later, I was informed that the animal was purging violently after the second ball, so I discontinued them and gave him a draught containing acid. sulph. dil. and æther sulph. At this time I noticed that in appearance he had altered considerably for the worse. Since my last visit he seemed to have wasted everywhere except where he should have done after purging. It now struck me very forcibly that, like his half-brother, he was doomed, and on my next visit I did not forget to give the owner my candid opinion that such was the case.

I need not enumerate the medicines he swallowed, nor mention the quantity of milk and other good things he had. Suffice it to say that he slowly but surely got worse. At my special request for a second opinion, Mr Goodall of Melton saw him with me, and after going thoroughly into the history of the case, as far as it was known to me, he quite agreed that it was a case of tuberculosis. Moreover, he gave me the clue I had been anxiously searching for. The grand-dam of these colts he knew well, and she had bred several remarkably good animals, but her own sister bred five or six colts, all of which died young, and under very similar circumstances to these. Although none had been examined after death, there is little doubt in my mind that they were victims to tuberculosis.

My patient lingered on until the end of September, when a friendly bullet laid him low. The autopsy revealed a similar, and if anything a worse, state than the other, particularly as regards the extent of the deposits in the liver.

Towards the end of October whilst making a call I noticed the same mare's foal of that year, and was so struck by his appearance that I at once expressed my conviction that he would shortly follow his halfbrother, which he did under 28 days. I also examined him post-mortem, and found him literally full of tuberculous deposits. The mare, barren, had been sold shortly before. I hear that she has been served again this year, and I intend if possible (she is many miles away) to watch her next production. She has had four foals, and three have already been accounted for. Her first when four years old apparently went wrong in his back, and as he did not improve, but got worse with treatment, was shot. I had no opportunity in this case of making a post-mortem examination, but I well remember the knacker saying that there was a "big lump" near his kidneys. 